\title{
Analysis and Planning of the Punge Intersection Roundabout Area in Banda Aceh City
}

\author{
Muhammad Isya $^{1 *}$, Yusria Darma ${ }^{1}$, Rachmat Taufiqy $^{1}$, Inseun Yuri Salena ${ }^{2}$ \\ ${ }^{1}$ Civil Engineering Department, Faculty of Engineering, Universitas Syiah Kuala, Banda Aceh, Indonesia \\ ${ }^{2}$ Civil Engineering Department, Faculty of Engineering, Universitas Teuku Umar, Aceh Barat, Indonesia \\ *Corresponding author: m_isya@unsyiah.ac.id
}

Article history

Received: 12.12.2020

Revised: 22.03.2021

Accepted: 25.04.2021

DOI:10.31629/jit.v2i1.3205

\begin{abstract}
The Punge intersection in Banda Aceh City is a four-armed intersection without traffic control devices such as traffic lights and roundabouts. The intersection performance from visual observation is currently very low, especially during peak hours. Therefore, it is presently considered necessary to evaluate road performance and carry out alternative handling planning. One alternative handling is to plan a roundabout at the intersection. Thus, this study aims to obtain road performance by comparing the use of a roundabout and without a roundabout. Analysis and planning using the MKJI and PTV Vissim 10.00-02 software methods. It requires data on traffic volume, road geometry, and environmental conditions around the location. The analysis of roundabout planning with the widening of each arm with the MKJI and Vissim methods produce the level of services to deliver the best decisions for improving the intersection performance.
\end{abstract}

Keywords: intersection, MKJI, Vissim, traffic control devices, peak hours

\section{Introduction}

An intersection can cause movement conflicts between vehicles, which is lead to the various traffic problems [1]. The Punge Intersection is a four-armed unsignalized intersection and has low performance. The spatial pattern formed in this intersection area consists of a diverse area filled with various activities such as trade, offices, social facilities, and settlements. This Punge intersection is the meeting point of the four intersection arms that bring together Sultan Iskandar Muda St (west and east arms) - Punge Blang Cut St and Jl. Cempaka Punge Jurong St.

From the problem stated, it is necessary to study alternative handling at the intersection. The objective of this study is to determine the performance of intersection by planning a roundabout to provide solutions or alternative solutions to the problem of low performance at the intersection. With a roundabout at this intersection, it is expected that the intersection performance will be better. Thus, the decision-maker will be able to have a basis in making decisions for handling these intersections.

\section{Materials and Methods}

\subsection{Data Collection}

Primary data required include environmental conditions, road geometry, traffic volume. Secondary data is in the form of data obtained from related agencies such as population data of the Central Statistics Agency (BPS) Banda Aceh. 
Data collection was carried out at the Punge area in Banda Aceh city of intersection. This data includes traffic volume per 15 minutes for 15 hours in 3 days, which has been converted from units of vehicles per hour to units of passenger cars per hour using the equivalent value of passenger cars. The light vehicle equivalent (LV) value is 1.0 , the heavy vehicle equivalent (HV) value is 1.3 , and the motorcycle equivalent value (MC) for an unsigned intersection is 0.5 , while for an intersection with a signal 0.4 for the condition protected and 0.2 for protected conditions. The traffic volume recorded was straight moving, right turning vehicles, and left turning vehicles at each arm of the intersection [2].

The analysis carried out intersection capacity and intersection performance, queue length (m), delay (seconds), and level of service (LOS). The calculation of intersections is based on the Indonesian Road Capacity Manual (MKJI 1997) and the PTV Vissim 10.00-02 (Vissim) software, as suggested elsewheres [2-4].

\subsection{Data Processing Method}

Data processing is carried out after the data from field observations have been recapitulated to be analyzed and simulated using Vissim software [3, 4]. The following are the stages of designing Vissim to run a simulation and get a traffic flow visualization video, namely (a) Create the link to make a connector, (b) determine the type of vehicle in 2D / 3D Models, add and adjust vehicle types on Vehicle Types and Vehicle Classes, adjust the speed of each vehicle in the preferred Speed Distribution, then adjust the Vehicle Compositions so that it can display the type of vehicle as desired, (c) input the traffic volume on the Vehicle Inputs first so that the vehicle will appear while running, (d) input traffic flow parameters and default traffic, (e) determine the route for Static Vehicle Routing Decisions, (f) Determine the traffic light cycle on the 3D Traffic Signal menu (only for scenario 2), (g) Setting the number of simulation trials, (h) perform calibration by method (trial and error) to achieve results that are close to the observational data. The value of the parameter of driving behavior is changed according to the estimated conditions in the applicable field, (i) run the simulation.

\section{Results and Discussions}

\subsection{Geometric Intersection}

Geometric intersection measurement results obtained directly at the research location by measuring the effective arm width of the approach on each arm using a meter tape. The geometric measurement results can be seen in Table 1 .

Table 1. Geometric Intersection

\begin{tabular}{clccc}
\hline No & \multicolumn{1}{c}{ Roads } & $\begin{array}{c}\text { Hand } \\
\text { Notation }\end{array}$ & $\begin{array}{c}\text { Road } \\
\text { Types }\end{array}$ & $\begin{array}{c}\text { Width } \\
(\mathbf{M})\end{array}$ \\
\hline $\mathbf{1}$ & $\begin{array}{l}\text { Minor arm of Cempaka } \\
\text { punge jurong road }\end{array}$ & A & 2/1UD & 6 \\
\hline $\mathbf{2}$ & $\begin{array}{l}\text { Major arm of Sultan } \\
\text { Iskandar Muda } \\
\text { Ulee Lheu) road }\end{array}$ & B & 6/2D & 9 \\
\hline $\mathbf{3}$ & $\begin{array}{l}\text { Minor Arm of Punge } \\
\text { Blang Cut road }\end{array}$ & $\mathrm{C}$ & 2/1UD & 7 \\
\hline $\mathbf{4}$ & $\begin{array}{l}\text { Major arm of Sultan } \\
\text { Iskandar Muda } \\
\text { city) }\end{array}$ & D & 6/2UD & 9 \\
\hline
\end{tabular}

\subsection{Traffic Flow Volume}

The traffic volume survey was conducted on Monday 26 August 2019, Thursday 22 August 2019, and Sunday 25 August 2019. The survey was carried out at 07.00-22.00 WIB for three (3) days using Closed Circuit Television (CCTV) tools. The time span for traffic volume data collection is carried out every fifteen minutes per hour. The observation result for traffic volume can be seen in figure 1 below.

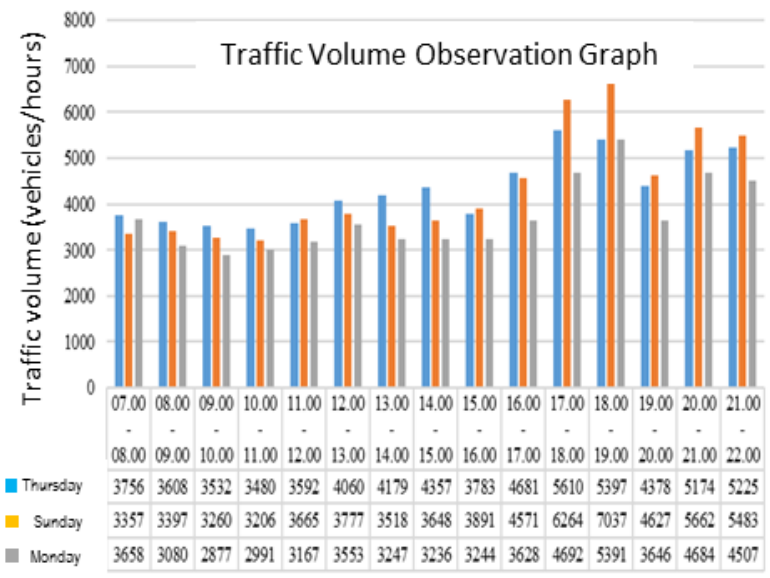

Figure 1. Intersection Traffic Volume During Peak Hours

Survey data on Sunday, August 25, 2019, during the afternoon rush hour at 18.00-19.00 WIB, is the peak hour compared to other days, with the 
planning of the roundabout there was a fairly large geometric change. The method is to widening every leg of the intersection. In the roundabout design planning, the type of roundabout used is the R10-22 type, it can be seen in Figure 4 and Table 2.

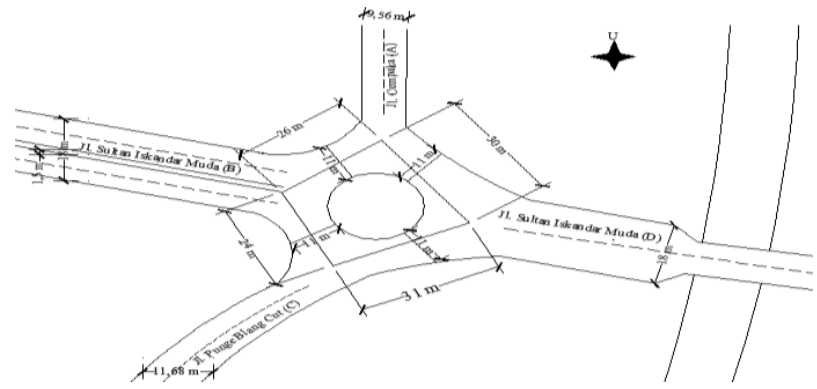

Figure 2. Lay out of Punge Intersection with Roundabout Design Plan

Table 2. Lay out of Punge intersection with Roundabout Design Plans

\begin{tabular}{|c|c|c|c|c|c|c|}
\hline \multirow{3}{*}{$\begin{array}{l}\text { Sec- } \\
\text { tion }\end{array}$} & \multicolumn{3}{|c|}{ Before (Existing) } & \multicolumn{3}{|c|}{ After (Planning) } \\
\hline & \multicolumn{2}{|c|}{ Entry Width } & \multirow[b]{2}{*}{$\begin{array}{c}\text { Entry } \\
\text { Width } \\
\mathrm{W}_{\mathrm{E}}(\mathrm{m})\end{array}$} & \multicolumn{2}{|c|}{ Entry Width } & \multirow{2}{*}{$\begin{array}{c}\text { Entry } \\
\text { Width } \\
\text { Average } \\
\mathrm{W}_{\mathrm{E}}(\mathrm{m})\end{array}$} \\
\hline & $\begin{array}{l}\text { Appr- } \\
\text { oach } 1 \\
(\mathrm{~m})\end{array}$ & $\begin{array}{l}\text { Appr- } \\
\text { oach } 2 \\
\text { (m) }\end{array}$ & & $\begin{array}{c}\text { Appr- } \\
\text { oach 1 } \\
\text { (m) }\end{array}$ & $\begin{array}{c}\text { Appr- } \\
\text { oach } 2 \\
(\mathrm{~m})\end{array}$ & \\
\hline A & 10 & 6 & 8,0 & 10 & 10 & 10,00 \\
\hline B & 10 & 9 & 9,50 & 10 & 11 & 10,50 \\
\hline $\mathrm{C}$ & 10 & 7 & 8,50 & 10 & 10 & 10,00 \\
\hline D & 10 & 9 & 9,50 & 10 & 12 & 11,00 \\
\hline
\end{tabular}

Determination the size of a roundabout with geometric changes in several arms of the road based on traffic volume and movement to identify the existing, which is the data can be used to input planning data for intersections with roundabouts. Thus, from MKJI 1997 the roundabout type R10-22 is obtained. From Figure 2 and Table 3 above, then an analysis is carried out based on the MKJI 1997 method. The results of the analysis are as can be seen in Table 3.

Table 3. Recapitulation of the 1997 MKJI calculation results

\begin{tabular}{|c|c|c|c|c|c|}
\hline \multirow{2}{*}{$\begin{array}{l}\text { Braided } \\
\text { Section }\end{array}$} & $\begin{array}{l}\text { Traffic } \\
\text { Delay }\end{array}$ & $\begin{array}{c}\text { Total Traffic } \\
\text { Delay }\end{array}$ & \multicolumn{3}{|c|}{$\begin{array}{c}\text { Queue } \\
\text { Opportunities }\end{array}$} \\
\hline & $\begin{array}{c}\text { DT } \\
\text { det/smp }\end{array}$ & $\begin{array}{c}\mathrm{DT}_{\mathrm{ToT} .}=\mathrm{Q} \times \mathrm{DT} \\
\text { det/hour }\end{array}$ & & $\mathrm{QP}$ & \\
\hline A & 2,33 & 4400,49 & 5,9 & - & 13,8 \\
\hline B & 2,84 & 6170,86 & 8,6 & - & 27,9 \\
\hline C & 2,53 & 5449,83 & 6,8 & - & 18,7 \\
\hline D & 2,25 & 4801,53 & 5,5 & - & 12,1 \\
\hline
\end{tabular}

Based on the calculation by doing road widening on all arms, the delay's value is 2.49 seconds, the queue opportunity value is $6.7 \%-18.13 \%$, and the service level of LOS B. This result is much better when compared to the intersection performance in this condition. existing in the form of free intersections, namely: delay $=36.49$ seconds, opportunity to queue $=57 \%-115 \%$, and service level (LOS) E [11]. Furthermore, the roundabout performance analysis was carried out using Vissim software. P parameters can be as seen in Figure 5.

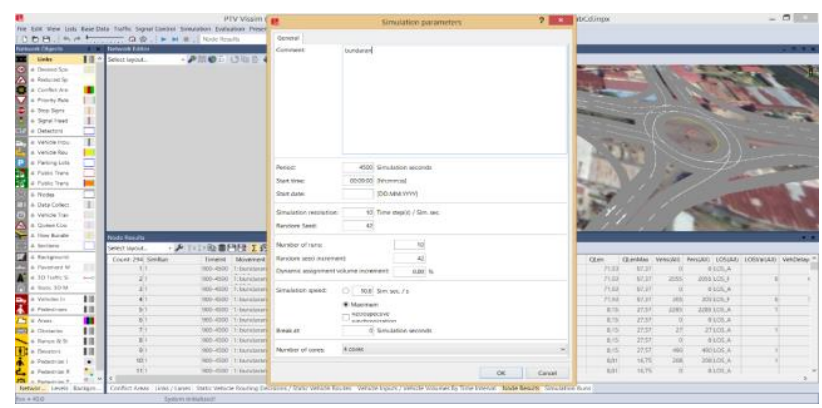

Figure 5. Roundabout Simulation Parameters

Figure 5 shows that multiplying the random seed 42 and a simulation run 10 times the parameters of traffic volume, capacity, the flow of the braided section, and delay to obtain accurate Measurement of Effectiveness (MOEs) results. We can see the simulation results in Table 4 .

Table 4. Recapitulation of simulation results using VISSIM software 10.00-02 (Roundabout)

\begin{tabular}{llll}
\hline MOVEMENT & $\begin{array}{l}\text { QLEN } \\
\text { MAX }\end{array}$ & $\begin{array}{l}\text { VEH DELAY } \\
(\text { ALL })\end{array}$ & $\begin{array}{l}\text { LOS } \\
\text { (ALL) }\end{array}$ \\
\hline B - B & 80,63 & 0 & - \\
\hline B - D & 80,63 & 47,19 & LOS E \\
\hline B - A & 80,63 & 0 & - \\
\hline B - C & 80,63 & 47,3 & LOS E \\
\hline D - B & 22,77 & 3,32 & LOS A \\
\hline D - D & 22,77 & 0 & - \\
\hline D - A & 22,77 & 4,95 & LOS A \\
\hline D - C & 22,77 & 0 & - \\
\hline D - C (KL) & 22,77 & 0,57 & LOS A \\
\hline A - D & 19,1 & 0,84 & LOS A \\
\hline A - B & 19,1 & 0 & - \\
\hline A - A & 19,1 & 0 & - \\
\hline A - C & 19,1 & 0,14 & LOS A \\
\hline C - D & 16,2 & 0 & LOS A \\
\hline C - B & 16,2 & 1 & LOS A \\
\hline C - A & 16,2 & 0,17 & - \\
\hline C - C & 16,2 & 0 & LOS A \\
\hline C - B (KL) & 16,2 & 0,08 & LOS B \\
\hline B - A (KL) & 19,1 & 15,43 & LOS A \\
\hline A - D (KL) & 19,49 & 0,41 & LOS C \\
\hline AVERAGE & 31,62 & 19,34 &
\end{tabular}

where: A Cempaka punge jurong road,

B Sultan Iskandar Muda road (from Ulee Lheu)

C Punge Blang Cut road

D Sultan Iskandar Muda road (from the City)

KL turn left keep going. 
Based on Table 4 above concludes that by installing a roundabout with a circle radius with type R10-22 and widening it at each intersection arm, the resulting average queue length value is $31.62 \mathrm{~m}$, a delay value of 19.34 seconds, and LOS $\mathrm{C}$ service level. The results obtained to provide better performance than the existing conditions with free intersections with performance parameters: delay $=25.32$ seconds, queue length $=$ $101.12 \mathrm{~m}$, and service level (LOS) E [11].

Based on the results of the data analysis, a discussion is carried out regarding traffic flow in existing conditions and with roundabout planning types R10-22. Furthermore, intersection performance is obtained based on the MKJI method (1997) and simulated with Vissim software to get the Measurement of Effectiveness (MOEs). The planned roundabout has a roundabout diameter of $20 \mathrm{~m}$ and requires the land acquisition of $\pm 850 \mathrm{~m} 2$ around the intersection, where for minor roads, land acquisition is $50 \mathrm{~m}$ long and 10 meters wide.

Calibration is carried out by changing the parameters of the driver's behavior (driving behavior) by trial and error by referring to the parameter values to produce output according to the reality in the field. The parameters and calibration values are in Table 5 below.

Table 5. Calibration and Simulation Model Validation

\begin{tabular}{|c|c|c|}
\hline \multirow[t]{2}{*}{ Parameters } & \multicolumn{2}{|c|}{$\begin{array}{l}\text { Driving behavior } \\
\text { parameters } \\
\text { (driving behavior) }\end{array}$} \\
\hline & Default & Change \\
\hline Average Standstill Distance & 2 & 0,5 \\
\hline Add. Part of Desired Safety Distance & 2 & 0,5 \\
\hline Mul. Part of Desired Safety Distance & 3 & 1 \\
\hline Nu mber of Observed Vehicle & 2 & 2 \\
\hline Lane Change Rule & $\begin{array}{l}\text { Free Lane } \\
\text { Selection }\end{array}$ & $\begin{array}{l}\text { Free Lane } \\
\text { Selection }\end{array}$ \\
\hline Desired Lateral Position & 1 & Any \\
\hline Lateral Distance Driving & 1 & 0,75 \\
\hline Lateral Distance Standing & 1 & 0,65 \\
\hline Safety Distance Reduction Factor & 0,6 & 0,45 \\
\hline Minimum Headway & 0,5 & 0,5 \\
\hline Random Seed & 42 & 10 \\
\hline Run Simulation & 1 & 10 \\
\hline
\end{tabular}

Table 5 above shows some of the parameters and their calibration values. The calibration results show that several parameters have the same value for each period. Figure 6 below shows the results before and after parameter calibration.
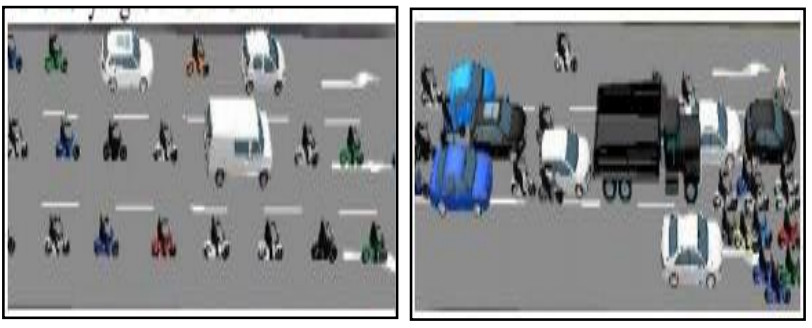

Figure 6. Conditions before and after calibration

Figure 6, shows a visual display on the Vissim software before and after the calibration. Before the calibration, the vehicle flow was very regular, and in their respective lanes, the distance between the vehicles was so vast. Meanwhile, after calibration the flow of vehicles is irregular, and there is mutual preparation, the distance between the vehicles is also very tight. It shows that the driver's traffic behavior is in accordance with the field conditions so that the simulation model can be accepted.

\section{Conclusion}

From the analysis carried out using R10-22 circular type, with a diameter of $20 \mathrm{~m}$, it can conclude that in calculations using the MKJI method, a delay of 2.49 seconds is obtained. The chances of queuing are $6.7 \%-18.13 \%$, and LOS B. in the Vissim Software, the calibration process has been carried out, resulting in a queue length of $31.62 \mathrm{~m}$, a delay of 19.34 seconds, and LOS C.

\section{Acknowledgement}

We would like to express our gratitude to Allah SWT and to all of many people whose name may not be enumerated. All contributions are sincerely appreciated and gratefully acknowledged.

\section{References}

[1] Taufiqy, R, 2016, Evaluasi Kinerja Persimpangan Tidak Bersinyal Pada Simpang Punge Banda Aceh, Fakultas teknik, Universitas Muhammaddiyah Aceh, Banda Aceh.

[2] Manual Kapasitas Jalan Indosia (MKJI), Direktorat Bina Marga, Departemen pekerjaan umum, 1997.

[3] VISSIM User Manual-version 8.0. PTV Planing Transport Verkehr AG, Karlsruhe, Germany, 2015.

[4] VISSIM User Manual-version 9.0. PTV Planing Transport Verkehr AG, Karlsruhe, Germany, 2016.

[5] Defry, B, Optimalisasi Geometrik Daerah Jalinan 
(Roundabout) Simpang Tujuh Ulee Kareng dengan Menggunakan Pendekatan Metode Simulasi Vissim 6.00-02, Universitas Syiah Kuala, Banda Aceh, 2017.

[6] Defry, B, Optimalisasi Geometrik Daerah Jalinan (Roundabout) Simpang Tujuh Ulee Kareng dengan Menggunakan Pendekatan Metode Simulasi Vissim 6.00-02, Universitas Syiah Kuala, Banda Aceh, 2017.

[7] Menteri Perhubungan RI, Peraturan Menteri Perhubungan Nomor: KM 14 Tahun 2006 Tentang Manajemen dan Rekayasa Lalu Lintas di Jalan. Departemen Perhubungan, Jakarta (2006).

[8] Juniardi, dkk, Analisis Arus Lalu Lintas Di Simpang Tak Bersinyal (Studi Kasus Simpang Timohodan Simpang Tunjung Kota Yogyakarta), Oktober 2009.
[9] Kurnia. dkk, Kapasitas Simpang Bersinyal dan Derajat Kejenuhannya (Studi Kasus Simpang IV Kota Lhokseumawe), Fakultas Teknik, Universitas Malikussaleh, Lhokseumawe, 2013.

[10] Suleman, F, Analisis Simpang Tak Bersinyal, Universitas Muhammaddiyah Yogyakarta, Teknik Sipil, 2016.

[11] Isya, M., Darma, Y., Sugiarto, S., Taufiqy, R., Zula, A.A., Kinerja Simpang Punge Blang Cut Kota Banda Aceh Menggunakan Metode MKJI dan Vissim, Jurnal Teknik Sipil \& Teknologi Konstruksi, Vol 6, No 2 (2020). 